DOI: 10.30519/ahtr.821699

Advances in Hospitality and Tourism Research (AHTR)

\title{
EXPLORING EXPERIENTIAL QUALITY IN SPORT TOURISM EVENTS: THE CASE OF MACAU GRAND PRIX
}

\author{
Shan WANG \\ Faculty of Hospitality and Tourism Management, Macau University of Science and Technology \\ ORCID: 0000-0001-7676-3424 \\ Yi LI ${ }^{1}$ \\ School of Business, Macau University of Science and Technology, Macau \\ ORCID: 0000-0003-2252-6495 \\ Jose Weng Chou WONG \\ Faculty of Hospitality and Tourism Management, Macau University of Science and Technology \\ ORCID: 0000-0002-3557-1829
}

\begin{abstract}
Understanding tourists' future behavior is significant for local tourism profits. This paper aims to examine the interrelationships among experiential quality, tourist satisfaction, experiential trust, sharing tourism experience on social media, and extension effect. 796 responses were collected in the 66th MGP (Macau Grand Prix) via questionnaires. The results reveal that four dimensions (physical environment quality, access quality, outcome quality, and enjoyment quality) have positive effects on experiential quality. In addition, the results also indicate the following relationships: Experiential quality has a significant effect on tourist satisfaction; experiential quality and tourist satisfaction positively influence experiential trust; tourist satisfaction and experiential trust have significant effects on behavior of sharing tourism experience on social media, and both tourist satisfaction and experiential trust positively influence extension effect. This paper identifies the dimensions of experiential quality in sport tourism events and it plays a leading role in extending literature on tourists' behavioral intentions of sharing behavior on social media and extension effect. The findings assist practitioners to implement marketing strategies of MGP, which enhance the extension effect and the new marketing promotions through social media. They also help various stakeholders such as destination managers and travel agents to trigger and increase local tourism profits.
\end{abstract}

\section{Article History}

Received 5 November 2020

Revised 1 February 2021

Accepted 15 March 2021

Available online 29 March 2021

\section{Keywords}

experiential quality

tourist satisfaction

experiential trust

sharing behavior on social media extension effect

Grand Prix

\footnotetext{
${ }^{1}$ Address correspondence to Yi Li, School of Business, Macau University of Science and Technology, Taipa, MACAU. E-mail: liyi@must.edu.mo
} 


\section{INTRODUCTION}

Sport tourism has become a prevalent topic in recent decades, garnering great attention in the academic field (Hinch \& Higham, 2001) due to the potential of sport events to attract people to travel and increase revenue, and to increase tourists' awareness of the tourism destination (Gibson et al., 2003). When a tourist destination holds sport tourism events, it will not only benefit tourists who travel to the destination intentionally as a result of this sport event, but also those who happen to be visiting at the right time and location to join the event (Deery et al., 2004). The Macau Grand Prix (MGP), which is held annually by local motoring enthusiasts for four days, has evolved into one of today's most well-known and demanding street circuit race events in the world (Han et al., 2018). The 2019 MGP in particular combined long, fast, straight, and sharply-twisting corners that were $6.2 \mathrm{~km}$ (3.8 miles) in length and $7 \mathrm{~m}$ (22.8 feet) in width. With its 60-year history, MGP has gained a worldwide reputation as a representative sport tourism event (Tang \& Wang, 2020). The 2019 MGP was held as a non-champion round of FIA's Formula Three championship and was open to drivers from all Formula Three championships.

Recent studies of such mega-events have garnered significant attention within current tourism fields. In specific, Henderson et al. (2010) performed the case of Singapore Grand Prix to examine the significance of the event within tourism contexts. Similarly, Dávid et al. (2018) identified the importance of the Hungarian Grand Prix, arguing that the event contributes greatly to the tourism industry, thus it is worth holding annually. Although sport tourism events have been widely discussed regarding their importance to tourism industry, a majority of studies have explored the economic impacts on such events (Daniels \& Norman, 2003; Duglio \& Beltramo, 2017; Kurtzman, 2005) and how to further improve or develop them (Perić et al., 2019; Podoler, 2016). Only a few studies have examined tourists' perception of sport tourism such as Zhang et al.'s (2019) examination of the antecedents of tourist's loyalty toward a sport event and the destination. Therefore, the antecedents, consequences, and mechanisms of tourists' perceptions on sport tourism events are still worth studying at length.

In order to understand tourists' satisfaction and behavioral intentions, the experiential quality was identified and examined in a few recent studies. Different from traditional service quality, experiential quality is regarded as a psychological outcome after the experience of involving tourism activities (Wu et al., 2018). Various studies have already 
examined the dimensions of experiential quality in specific types of tourism such as theme parks (Kao et al., 2008), cruises (Wu et al., 2018), or the golf field (Wu \& Ai, 2016). However, no existing empirical studies have focused on the social media sharing behavior and extension effect regarding the experiential quality of events or festivals. Different from other tourism contexts, sport tourism events like MGP are normally held for a few days, and tourists are subjected to sport events rather than attractions or dining; because the experiential quality of such events will greatly influence tourists' perceptions and behavior, there is a need to study the experiential quality with sharing behavior.

Many previous studies on experiential quality and tourist perception revisit intention or loyalty as the outcome variables. Although those factors are still valuable to predict tourist behavior, some researchers believed that other consequences were also important and should be addressed. For example, under the concept of brand strategies, some studies argued that a successful brand should consider its brand image and extension effect (Dacin \& Smith, 1994). In the setting of green hotel, Wu et al. (2016) demonstrated that experiential quality has significant impacts on hotel green image, which indicates the importance of a brand image on the customer's experiential quality, thus it leads to future behavioral intentions. Also, social media is used increasingly in current years and has become a major part of the tourism industry, directly affecting its practices (Munar \& Jacobsen, 2014); studies have shown that sharing tourism experiences on social media will eventually replace some of the traditional channels of promotion and thus needs to be taken seriously (Wong et al., 2020). One of the newest studies on experiential quality in the hospital service setting revealed that a hospital's social media engagement and experiential quality have a positive association (Lee et al., 2020). The purposes of sport tourism events are to encourage tourists' continuous participation and expand destination awareness because Choi and Bum (2020) and Kim (2020) suggested that continuous participatory behavior patterns have important effects on different sport activities, and, in the case of the MGP, destination awareness in the long-term is more important. Therefore, social media is a platform that produces an influential effect and the behavior of sharing tourism experiences on social media is meaningful in this study. As LópezCarril et al. (2020) discussed, social media has revolutionized the sport industry and its implications hold significant meaning for sport managers. Also, the promotional activities are important in the context of MGP since their product brands and tourist locations are advertised. These activities that extend beyond MGP provide opportunities to promote products and 
increase local economic development. Gu (2006) also discussed how product differentiation is significant for Macau's revenue management. Therefore, these new variables, sharing behavior on social media and extension effect, are meaningful and valuable to measure in this study because of their potential associations with experiential quality in the tourism setting.

The present study aims to develop an understanding of experiential quality in sport tourism events and explore factors that may influence future tourist behavior regarding sharing behavior on social media and extension effect. It devoted to solving the following research questions: (A) What dimensions of experiential quality are significant in the context of sport tourism events?; (B) Does experiential quality in the context of sport tourism events reflect tourist satisfaction and experiential trust?; and (C) Whether the sharing behaviors on social media and extension effects can function or not after tourists' perception in the sport tourism events? The main contributions of this study are twofold. Theoretically, this research addresses sport tourism events by linking experiential quality and tourists' further perceptions and behaviors using a multidimensional and hierarchical approach. It clarifies how experiential quality motivates tourist behavior in sport tourism events, an objective of which is rare in the existing literature. Secondly, this study is one of the first to explore functions of sharing tourism experiences on social media and extension effect in the setting of sport tourism. Practically, the findings of this study will help sport tourism event organizers to evaluate their event design and marketing promotions in order to increase the extension effect and the new style of marketing promotions through social media. It will also assist various practitioners such as destination managers, travel agents, or other stakeholders in designing attractive services or tourism products to trigger and increase tourists' experiential quality.

\section{LITERATURE AND HYPOTHESIS DEVELOPMENT}

\section{Mega-events and Sport Tourism Events}

A mega-event usually refers to a large-scale cultural, commercial, and sporting event (Roche, 2002, p. 1) that generates economic benefits and has significant social and cultural impacts on tourism destination (Wang et al., 2012). Mega-events have both tangible and intangible effects, attracting visitors to tourism destinations, adding exposure for tourism destinations, and boosting local economies (Arnegger \& Herz, 2016); thus, mega-events play an important role in destination' tourism development. Many scholars 
have studied mega-events from both resident and tourist perspectives: Gursoy et al. (2017) examined the influence of residents' trust of government and organizers regarding their support of the 2014 FIFA World Cup; Lovegrove and Fairley (2017) compared residents' perception of respect to non-host cities and the corresponding host city of the 2018 Gold Coast Commonwealth Games; and Sox et al. (2020) explored residents' perception toward assisting in the organization of mega-events and advancing knowledge in this area. Other studies emphasize the valuable experience and perception of tourists; for example, Song et al. (2019) examined the relationship between tourists' emotional response and perception in the context of the 2014 Incheon Asian Games, and Risitano et al. (2017) discussed the influence of national cultural value on tourists' experience and perception in the America's Cup World Series (ACWS). These examples of mega-event research all discussed the significant role of experience, which influences perception and behavioral outcomes.

As one of the tourism sectors of mega-events, sport tourism events have direct and indirect economic and social implications and improve the visibility and attractiveness of tourism destinations (Duglio \& Beltramo, 2017). A sport tourism event is defined as a smaller-scale sport event than a mega-event that is recognized as a place regeneration mechanism (Ritchie \& Adair, 2004). As stated by Chen (2016) in marathon study, a sport tourism event is a newer trendy research segment and experience than sport megaevents that has a positive impact on further behavioral intentions (Sorrentino et al., 2020). As an antecedent of tourist behavior, the use of experience has a significant impact on destination success. Specifically, Cetin (2020) stated that customer experience and service quality could better explain positive customer behavior, and Al-Msallam (2020) discussed that both tourists' negative and positive perceptions have a significant impact on overall behavior. Therefore, the present study attempts to fill the research gap and focus on experiences in sport tourism event contexts to determine tourist perception and future behavioral intentions.

\section{Experiential Quality}

An experience is a distinct economic offering, the design of which is a competitive advantage (Chang \& Horng, 2010). Yuan and Wu (2008) stated that gaining experience will lead to a difference in product consumption. The concept of experience in the business context has been widely studied from the perspective of the consumer or product. In the tourism setting, many researchers use experiential quality (EXQ) to study tourists' overall experiences and attitudes. In a study on heritage tourism, EXQ refers to a 
"perceived judgement about superiority of the tourists' experience" (Wu \& Li, 2017, p. 907). In another study, EXQ is defined by Chang and Horng (2010, p. 2403) as "how customers feel emotionally during their service process, including interacting with service surroundings." Following Cole and Scott's (2004) definition of EXQ, it is understood in this study as a psychological experience from suppliers and opportunities brought from visitors. Specifically, all of the aforementioned studies found that the higher level of EXQ generates a more positive level of tourist attitude and behavioral intention; in this study, the following examples will use different dimensions to measure EXQ.

Several studies (Cole \& Scott, 2004; Wu \& Li, 2017; Wu et al., 2018) already discussed that multidimensional and hierarchical models should be used when studying EXQ. Previous studies have identified several dimensions of EXQ; for example, Otto and Ritchie (1996) were the first to identify scales of EXQ, which hedonics, peace of mind, involvement, and recognition are more applicable in leisure and tourism studies. In a service setting, Chang and Horng (2010) developed the scale of EXQ to the following factors: physical surroundings, customers themselves, service providers, other customers, and customer companies. $\mathrm{Wu}$ and colleagues (Wu \& Ai, 2016; Wu \& Li, 2017; Wu et al., 2018a) further expanded the framework of EXQ, outlining five additional elements: interaction quality (IQ), physical environment quality (PEQ), access quality (AQ), outcome quality (OQ), and enjoyment quality (EQ). Since this framework was utilized in various areas such as cruise field, theme park, and the heritage industry, we can conclude that EXQ has different sub-dimensions in a variety of research settings. As suggested by $\mathrm{Wu}$ and $\mathrm{Li}$ (2017), the dimensions of EXQ should be examined under different research settings; thus, this study will utilize this framework and attempt to explore the dimensions of sport tourism event's EXQ. What follows is a discussion of each of the five elements of EXQ.

Being the most important components of service quality (Grönroos, 1988), interaction quality (IQ) indicates the customer's perception of how the service is delivered during the consumption experience (Brady \& Cronin, 2001; Lemke et al., 2011). Lu et al. (2009) defined physical environment quality (PEQ) as how tangible services are delivered from service providers to customers and how the perception of customers is presented during the experience. This dimension is utilized in several studies (Wu et al., 2017; Wu \& Li, 2017) to evaluate EXQ. The definition of third dimension, outcome quality (OQ), is the outcome of what customers left after finishing the service (Gronroos, 1984) and several studies (Choi 
and Kim, 2013) revealed that OQ is related to customers' EXQ. The fourth dimension, access quality (AQ), refers to the degree of speed and convenience in which customers receive the service (Shonk \& Chelladurai, 2008). In a study of green hotel context, Wu and Ai (2016) identified that AQ is positively related to EXQ. This dimension can be used to explore the convenience level of customers arriving in Macau and reaching the MGP. The last dimension, enjoyment quality (EQ), indicates the degree of positive emotion that customers experience during the event (Lopez, 2011). This dimension in this study refers to customers' levels of pleasure during MGP activities.

Several researchers have previously revealed that IQ, OQ, PEQ, AQ, EQ positively associated with EXQ, but different authors have had differing opinions regarding the importance of each dimension in a particular research setting. For instance, $\mathrm{Wu}$ and colleagues (2016) proposed that PEQ, $A Q, O Q$ and administration quality are influential dimensions in green hotel context; Wu et al. (2018) proposed that IQ, OQ, PEQ, AQ all have significant effects on EXQ in cruise setting; and Wu et al. (2017) proposed that PEQ, OQ, IQ, EQ, and AQ are significant in zoo visitors' EXQ. Since EXQ is one of the important factors influencing tourists' behavior in the tourism setting, it is necessary to discuss whether these dimensions have effects on EXQ in sport tourism events. Accordingly, this study formulates following hypotheses examining EXQ in sport tourism events:

H1a: Interaction quality (IQ) has positive effect on experiential quality (EXQ).

H1b: Physical environment quality (PEQ) has positive effect on experiential quality (EXQ).

H1c: Outcome quality (OQ) has positive effect on experiential quality (EXQ).

H1d: Access quality $(A Q)$ has positive effect on experiential quality (EXQ).

H1e: Enjoyment quality (EQ) has positive effect on experiential quality (EXQ).

\section{Tourist Satisfaction and Experiential Trust}

Satisfaction indicates the difference between customers' expectations and perceived performance during service encounters (Oliver, 1980). In the tourism context, tourist satisfaction (TS) is defined by del Bosque and Martín (2008, p. 553) as "tourists' cognitive-affective state derived from overall their tourism experience". A tourist's satisfaction or dissatisfaction of an experience is closely related to their intention of returning to the destination (Alegre \& Garau, 2010). Recent studies that refer to the overall satisfaction during the visit experience have found that tourists mostly 
compare their experiences to prior ones, which leads to different emotions (Chen \& Chen, 2010). Thus, understanding satisfaction as the antecedent of positive customer experience is significant. Specifically, theme park studies by Kao et al. (2008) indicated that EXQ has positive effect on TS; heritage studies by Chen and Chen (2010) indicated that EXQ is positively related to TS; and cruise studies by $\mathrm{Wu}$ et al. (2018) also revealed that EXQ has significant and positive effect on TS. From discussion above, this study generates the hypothesis as following:

H2: Experiential quality (EXQ) has positive effect on tourist satisfaction (TS).

In addition, Rousseau et al. (1998, p. 395) define perceived trust as "a psychological state to accept vulnerability based on another person's intention or behavior expectation" and perceived trust is the antecedent of customer satisfaction (Swanson et al., 2007). In line with the definition provided by Rose et al. (2012), experiential trust (ET) in this study indicates to tourists' perception of reducing uncertainty and risk while increasing willingness of travel. Lee and Chung (2009) and Loureiro and González (2008) have confirmed that customer satisfaction is positively related to trust and the positive level of trust affects satisfaction. In the context of brand management, this also indicates that the higher level of brand satisfaction generates the higher level of brand trust (Chinomona, 2013). In another study of EXQ, Foster and Cadogan (2000) demonstrated that the perceived quality positively influenced customer trust. As indicated by these studies on the literature of trust, in regard to either customer trust or brand trust, these variables all relate to satisfaction, which indicates one's behavior of willingness to return or recommend. This leads to the following hypotheses:

H3a: Experiential quality (EXQ) has positive effect on experiential trust (ET).

H3b: Tourist satisfaction (TS) has positive effect on experiential trust (ET).

\section{The Behavior of Sharing Tourism Experience On Social Media}

Kaplan and Haenlein (2010, p. 61) define social media as "a group of Internet-based applications that build on the ideological and technological foundations of Web 2.0 and allow the creation and exchange of usergenerated content". Many studies have discussed how social media influences tourism destinations. With the adoption and continuous growth of digital technology, recent studies on social media and sharing experiences on similar platforms are being conducted and published all over the world (Sotiriadis, 2017). Chiu et al. (2006) found that having similar 
interests and goals and sharing experiences on social media boost online social interactions. Sotiriadis (2017) stated that the development of social media has had a significant impact on consumer behavior, creating a new channel for individuals to share experiences or express desires. In the tourism context, some studies have previously explored the outcomes of sharing tourism experiences. For example, Kang and Schuett (2013) indicated that consumers share experiences in a variety of ways, including text, photos, audio, or video, and concluded that shared information is important, especially in the post-trip stage, for other potential travelers to make decisions. Similarly, Ryu and Feick (2007) found that sharing experiences and recommending consumption experiences significantly boosts post-evaluation satisfaction and increases travelers' overall positive evaluation (Kim \& Fesenmaier, 2017). Thus, sharing information on social media (BS) is important for tourist destinations and their tourism development. In the present study, sport tourism events not only create benefits for events, but also promote local tourism development, especially for tourism destinations like Macau that are looking to diversify (Lai \& Wong, 2021). The quality of tourists' experiences influences satisfaction, which, in turn, affects sharing behavior on social media platforms. However, a focus on social media platform sharing behavior in the context of sport tourism events is limited. Hence, this study aims to fill the literature, generating the following hypothesis:

H4a: Tourist satisfaction (TS) has positive effect on behavior of sharing experiences on social media (BS).

In the context of marketing strategies, consumers who are confident with the products or suppliers are more likely to buy products (Loureiro \& González, 2008). Trust is considered one of the most important factors of online platforms (Corritore et al., 2003; Flavián et al., 2006). A study by Wu et al. (2018) found that cruise customers are more willing to trust the cruise company because EXQ and TS are related to behavior intention; their results also showed that behavior intention is positively related to trust. The credibility of sharing experience affects the adoption of information and travel intentions (Bae et al., 2017). The higher level of trust toward the product or brand generates the higher motivation of sharing behavior (Loureiro \& Gonzalez, 2008). While these studies focus on quality, satisfaction, and behavioral intention from a marketing perspective, they do not adequately investigate the relationship between trust and sharing behavior on social media. This study aims to explore whether tourists' trust (ET) of the MGP event will influence the behavior of sharing experiences 
(BS) on social media. Therefore, this study formulates the following hypothesis:

H4b: Experiential trust (ET) has positive effect on behavior of sharing experiences on social media (BS).

\section{Extension Effect}

Extension effect (EE) has previously been studied in the context of cobranding, which attitude changes among customers are determined by three factors: extension effect, mutual effect, and reciprocal effect (Lee \& Decker, 2009). Specifically, extension effect (EE) is defined as the effect of future behavior that will occur after responsive consumption (Hjalager \& Konu, 2011, p. 892). From the perspective of co-branding, a local festival or event plays an important role in building relationships with other brands; in other words, EE is highly relevant to sport tourism events. Song et al. (2017) indicated that an EE had a significant impact on the Osong C\&B expo, leading customers to buy products during the festival and remember the brands from the festival after the event ended. Similarly, Song et al. (2017) demonstrated that TS positively influences theme awareness, which positively influences the EE. For example, tourists are more likely to buy a souvenir or choose a brand advertised by the event in the future if they are more satisfied with their experience. Thus, extension is a significant factor for a successful sport tourism event. However, these studies are mostly related to the visitors' awareness of a brand, overlooking the EE on such festivals; therefore, this area needs more attention to determine the longterm success of an event and the destination's tourism development as a whole. With support of the aforementioned studies, we present the following hypothesis:

H5a: Tourist satisfaction (TS) has positive effect on extension effect (EE).

Several studies have also explored the relationship between ET and EE. For example, by studying nine service products, Reast (2005) found that brand trust is significantly related to extension acceptance and that highly trusted brands have a positive EE. In addition, Völckner and Sattler (2006) found that a customer's confidence in the parent brand has an important impact on EE; trust in a product or event is the antecedent of satisfaction, which, in turn, influences tourists' ability to remember a brand. Therefore, this study formulates the following hypothesis:

H5b: Experiential trust (ET) has positive effect on extension effect (EE). 


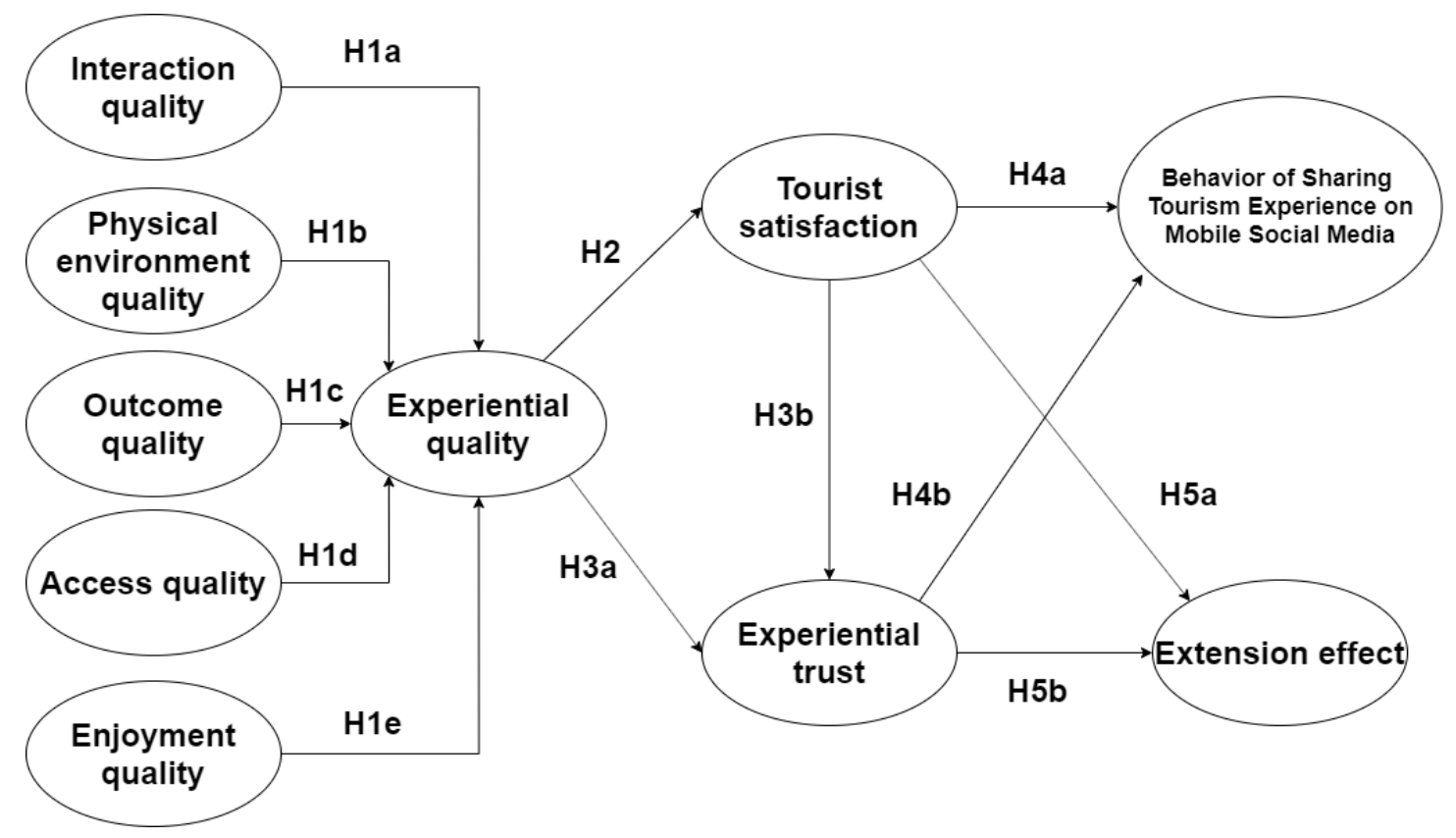

Figure 1. Research model

\section{METHODOLOGY}

\section{Study Site, Sample and Data Collection}

As one of the most well-known and prestigious brands in the international racing arena, the Macau Grand Prix (MGP) has gained a worldwide reputation as an FIA Formula Three World Cup and it has been passed for one of the most challenging racetrack, representative of sport tourism events around the world (Tang \& Wang, 2020). The MGP has shown a consistent effort to benefit Macau's tourism. Specifically, MGP organizers have cooperated with other industries such as car servicing and photographic gaming. From a research perspective, Grand Prix has served as one of the most important events for the field of sport tourism. In 2019, the MGP was hosted for four days, from November 14 to 17. Data were collected by distributing questionnaires across three entrance spots of MGP, as well as the nearby bus station where tourists were likely to go when they leave the event. Prior to the distribution, 50 pilot tests were conducted among MGP tourists to test the appropriateness of the measurement items and to receive feedback related to the questionnaire design. Finally, participants confirmed that there were no difficulties in understanding the questions. 
Table 1. Background of respondents $(N=796)$

\begin{tabular}{|c|c|c|c|}
\hline & & Frequency & Percent \\
\hline \multirow[t]{2}{*}{ Gender } & Male & 552 & 69.3 \\
\hline & Female & 244 & 30.7 \\
\hline \multirow[t]{9}{*}{ Age } & $18-20$ & 82 & 10.3 \\
\hline & $21-25$ & 173 & 21.7 \\
\hline & $26-30$ & 129 & 16.2 \\
\hline & $31-35$ & 135 & 17.0 \\
\hline & $36-40$ & 83 & 10.4 \\
\hline & $41-45$ & 70 & 8.8 \\
\hline & $46-50$ & 48 & 6.0 \\
\hline & $51-55$ & 33 & 4.1 \\
\hline & Over 55 & 43 & 5.4 \\
\hline \multirow[t]{3}{*}{ Marital status } & Married without children & 95 & 11.9 \\
\hline & Married with children & 295 & 37.1 \\
\hline & Single & 406 & 51.0 \\
\hline \multirow[t]{6}{*}{ Education level } & Secondary school or below & 44 & 5.5 \\
\hline & High school & 132 & 16.6 \\
\hline & College or university & 484 & 60.8 \\
\hline & Vocational/technical school & 41 & 5.2 \\
\hline & Graduate school or above & 91 & 11.4 \\
\hline & Others & 4 & 0.5 \\
\hline \multirow[t]{5}{*}{ Visit with } & Alone & 142 & 17.8 \\
\hline & Spouse/couple & 108 & 13.6 \\
\hline & Family/Relative & 109 & 13.7 \\
\hline & Friends & 408 & 51.3 \\
\hline & Travel Group & 29 & 3.7 \\
\hline \multirow{5}{*}{$\begin{array}{l}\text { Times to attend } \\
\text { car race }\end{array}$} & 1 time & 332 & 41.7 \\
\hline & 2 times & 167 & 21.0 \\
\hline & 3 times & 92 & 11.6 \\
\hline & 4 times & 37 & 4.6 \\
\hline & 5 times or more & 168 & 21.1 \\
\hline \multirow[t]{10}{*}{ Occupation } & Management/Administrative staff & 135 & 17.0 \\
\hline & White-collar & 88 & 11.1 \\
\hline & Professional & 121 & 15.2 \\
\hline & Salespeople & 61 & 7.7 \\
\hline & Service staff & 46 & 5.8 \\
\hline & Housewife & 9 & 1.1 \\
\hline & Student & 156 & 19.6 \\
\hline & Self-employed & 149 & 18.7 \\
\hline & Unemployed & 9 & 1.1 \\
\hline & Retired & 22 & 2.8 \\
\hline \multirow{6}{*}{$\begin{array}{l}\text { Travel spending } \\
\text { in this Macao } \\
(\mathrm{RMB})\end{array}$} & 500 or less & 48 & 6.0 \\
\hline & $501-2000$ & 130 & 16.3 \\
\hline & $2001-4000$ & 153 & 19.2 \\
\hline & $4001-6000$ & 134 & 16.8 \\
\hline & $6001-8000$ & 117 & 14.7 \\
\hline & 8001 or above & 214 & 26.9 \\
\hline
\end{tabular}


Systematic random sampling was performed in this study, in which every tenth participant who visited the MGP was approached to participate. A screening question prior to survey distribution was asked, which was, "Are you a tourist participating in 2019 Macao Grand Prix?" If the respondent answered "no" to the screening question or declined the request, the next tenth participant who visited MGP was subsequently approached. Four well-trained research assistants were charged to distribute the questionnaires at the three entrance spots and the entire process lasted four days, from November 14 to 17, 2019. In the first section of the questionnaire, respondents were reached by their agreement and invited to fill the questionnaire on a 7-point Likert scale, from " 1 " as strongly disagree to " 7 " as strongly agree. The second section consisted of general background information, which is shown in Table 1. By the end of the event, 820 surveys were collected, 796 of which were valid for further analysis; 24 were removed because most of the measurement items were given the same rating.

\section{Measurement}

This study adopted multiple measurement items to avoid single measurement errors and produce more representative results. To develop each research item, we conducted a comprehensive literature review on research related to EXQ and tourist behavior, including TS, ET, BS, and EE. The measurable items of EXQ include those of IQ (3 items), PEQ ( 3 items), OQ (3 items), AQ (3 items), and EQ (4 items), respectively. The measurement items of $\mathrm{IQ}, \mathrm{PEQ}, \mathrm{AQ}$, and $\mathrm{OQ}$ are derived from previous measurement scales (Brady \& Cronin, 2001; Wu et al., 2017). The measurements of EQ are derived from $\mathrm{Wu}$ et al. (2017). TS measurement items are from He et al. (2018). Measurable items of BS are derived from Wong et al. (2020). The measurement scale of ET is derived from $\mathrm{Wu}$ et al. (2018) and Jin et al. (2018). Last, the items of EE are derived from Lee and Decker (2009) and Song et al. (2017). Table 2 shows the measurable items of ten constructs. 
Advances in Hospitality and Tourism Research, 9 (1)

Table 2. Descriptive analysis of 24 measurement items

\begin{tabular}{|c|c|c|c|c|c|c|c|c|c|}
\hline & Measurement item & Mean & S.D. & $\begin{array}{c}\text { Excess } \\
\text { Kurtosis }\end{array}$ & Skewness & $\begin{array}{c}\text { Factor } \\
\text { loading }\end{array}$ & $\begin{array}{c}\text { Cronbach's } \\
\text { Alpha }\end{array}$ & $\mathrm{CR}$ & AVE \\
\hline & Interaction quality (IQ) & & & & & & 0.948 & 0.966 & 0.906 \\
\hline IQ1 & The interaction I have with the staff is of a high standard. & 5.431 & 1.346 & 0.149 & -0.66 & 0.953 & & & \\
\hline IQ2 & I feel good about the interaction I have with the staff. & 5.315 & 1.351 & -0.167 & -0.516 & 0.955 & & & \\
\hline \multirow[t]{2}{*}{ IQ3 } & Overall., I would say the quality of my interaction with the staff is excellent. & 5.389 & 1.36 & 0.022 & -0.621 & 0.947 & & & \\
\hline & Physical environment quality (PEQ) & & & & & & 0.919 & 0.949 & 0.861 \\
\hline PEQ1 & I believe that the physical environment in this event is excellent. & 5.514 & 1.243 & 0.39 & -0.723 & 0.925 & & & \\
\hline PEQ2 & The physical environment in this event is of a high standard. & 5.46 & 1.256 & -0.094 & -0.616 & 0.941 & & & \\
\hline \multirow[t]{2}{*}{ PEQ3 } & I am impressed with the quality of this event's physical environment. & 5.506 & 1.261 & -0.005 & -0.664 & 0.917 & & & \\
\hline & Outcome quality (OQ) & & & & & & 0.91 & 0.944 & 0.848 \\
\hline OQ1 & I feel good about what the staff provide to their visitors. & 5.401 & 1.29 & 0.173 & -0.64 & 0.906 & & & \\
\hline OQ2 & I always have an excellent experience while visiting this event. & 5.544 & 1.242 & 0.635 & -0.809 & 0.924 & & & \\
\hline \multirow[t]{2}{*}{ OQ3 } & The quality of service I receive in this event is excellent. & 5.456 & 1.262 & 0.331 & -0.737 & 0.933 & & & \\
\hline & Access quality (AQ) & & & & & & 0.744 & 0.855 & 0.663 \\
\hline AQ1 & I feel free to explore and there are no restrictions to access as tourists. & 5.372 & 1.457 & -0.046 & -0.729 & 0.834 & & & \\
\hline AQ2 & The event where I just visited is close to everywhere I want to go. & 5.211 & 1.367 & -0.225 & -0.518 & 0.851 & & & \\
\hline \multirow[t]{2}{*}{ AQ3 } & Coming to Macau is so easy. & 5.666 & 1.403 & 0.582 & -1.021 & 0.754 & & & \\
\hline & Enjoyment quality (EQ) & & & & & & 0.926 & 0.948 & 0.819 \\
\hline EQ1 & I think taking part in this event would bring me pleasure. & 5.913 & 1.127 & 0.579 & -0.948 & 0.905 & & & \\
\hline EQ2 & I think taking part in this event would make me feel relaxed. & 5.756 & 1.237 & 1.15 & -1.072 & 0.882 & & & \\
\hline EQ3 & I think combining this event with visiting procedures would be enjoyable. & 5.75 & 1.109 & 0.778 & -0.795 & 0.926 & & & \\
\hline EQ4 & I think combining this event with visiting procedures would make me feel fantastic. & 5.727 & 1.161 & 0.433 & -0.786 & 0.906 & & & \\
\hline
\end{tabular}




\begin{tabular}{|c|c|c|c|c|c|c|c|c|c|}
\hline & Experiential quality (EXQ) & & & & & & 0.869 & 0.919 & 0.792 \\
\hline EXQ1 & $\begin{array}{l}\text { I believe that visiting this event is going to provide the visitor with an interestingly educational and } \\
\text { instructive experience. }\end{array}$ & 5.472 & 1.256 & -0.033 & -0.617 & 0.87 & & & \\
\hline EXQ2 & The quality of this event could be considered superior when compared to other events. & 5.454 & 1.211 & 0.356 & -0.718 & 0.9 & & & \\
\hline \multirow[t]{2}{*}{ EXQ3 } & Taking part in this event is a pleasant experience. & 5.774 & 1.161 & 0.758 & -0.912 & 0.9 & & & \\
\hline & Tourist satisfaction (TS) & & & & & & 0.935 & 0.958 & 0.885 \\
\hline TS1 & Overall, I am satisfied with my visit to event. & 5.794 & 1.145 & 1.324 & -1.033 & 0.922 & & & \\
\hline TS2 & Compared to my expectation's situation, I am satisfied with my visit to event. & 5.683 & 1.2 & 1.352 & -1.033 & 0.953 & & & \\
\hline \multirow[t]{2}{*}{ TS3 } & Compared to the ideal situation, I am satisfied with my visit to event. & 5.639 & 1.227 & 0.875 & -0.912 & 0.946 & & & \\
\hline & Experiential trust (ET) & & & & & & 0.932 & 0.956 & 0.88 \\
\hline ET1 & I think this event is reliable. & 5.808 & 1.153 & 1.347 & -1.05 & 0.928 & & & \\
\hline ET2 & I have confidence in this event. & 5.784 & 1.177 & 1.267 & -1.047 & 0.954 & & & \\
\hline \multirow[t]{2}{*}{ ET3 } & I think this event has high integrity. & 5.793 & 1.14 & 1.02 & -0.917 & 0.931 & & & \\
\hline & Behavior of Sharing Tourism Experience on Mobile Social Media (BS) & & & & & & 0.952 & 0.962 & 0.807 \\
\hline BS1 & I would like to chat with friends about my event experience on mobile social media. & 5.621 & 1.324 & 1.424 & -1.143 & 0.86 & & & \\
\hline BS2 & I would like to create posts about my experience on mobile social media during this event. & 5.554 & 1.433 & 1.118 & -1.157 & 0.925 & & & \\
\hline BS3 & I would like to post messages about my tourism experience on mobile social media during this event. & 5.523 & 1.411 & 0.871 & -1.048 & 0.937 & & & \\
\hline BS4 & $\begin{array}{l}\text { I would like to get replies from friends about my posted tourism experience on mobile social media } \\
\text { during this event. }\end{array}$ & 5.496 & 1.422 & 1.031 & -1.103 & 0.927 & & & \\
\hline BS5 & $\begin{array}{l}\text { I would like to receive 'Likes' regarding my tourism experience on mobile social media during this } \\
\text { event. }\end{array}$ & 5.569 & 1.495 & 1.012 & -1.162 & 0.904 & & & \\
\hline \multirow[t]{2}{*}{ BS6 } & I would like to post photos about my tourism experience on mobile social media during this event. & 5.435 & 1.565 & 0.721 & -1.082 & 0.83 & & & \\
\hline & Extension effect (EE) & & & & & & 0.808 & 0.883 & 0.715 \\
\hline EE1 & I will remember the event experience for a long time. & 5.67 & 1.256 & 0.674 & -0.943 & 0.826 & & & \\
\hline EE2 & I will bring back gifts and souvenirs from the event. & 4.732 & 1.841 & -0.647 & -0.552 & 0.861 & & & \\
\hline EE3 & I think the souvenirs here are unique. & 4.715 & 1.746 & -0.466 & -0.565 & 0.85 & & & \\
\hline
\end{tabular}

Note: $\mathrm{CR}=$ Composite Reliability; AVE = Average Variance Extracted 


\section{FINDINGS}

The analysis was conducted using SmartPLS because PLS-SEM has advantages in analyzing small or middle size samples (Black et al., 2010), and can also be used with normal or non-normal data by using bootstrapping techniques with 796 cases and 5000 samples to assess path coefficients (Hair et al., 2016). The respondent background is shown in Table 1, indicating that the majority of the respondents were male $(69.3 \%)$, between 21 and 35 years of age (54.9\%), and had visited MGP less than 4 times $(74.3 \%)$.

\section{Reliability, Validity and Correlation}

The descriptive analysis of 24 measurement items is shown in Table 2. The table demonstrates all important indexes for 24 items. The values of all factor loadings are greater than 0.7 and that of Cronbach's Alphas are all greater than 0.7; the CR of those items is greater than 0.7 and the AVE exceeds 0.5 . Table 3 performs the discriminant validity test. The values of correlation between two variables are all significant and range from 0.394 to 0.808 . The square root of AVE for each construct, ranging from 0.814 to 0.952 , is higher than the correlation values between that construct and other constructs, hence the discriminant validity is also ensured.

Table 3. Discriminant Validity

\begin{tabular}{lllllllllll}
\hline & AQ & BS & EE & EQ & ET & EXQ & IQ & OQ & PEQ & TS \\
\hline AQ & $\mathbf{0 . 8 1 4}$ & & & & & & & & & \\
BS & 0.394 & $\mathbf{0 . 8 9 8}$ & & & & & & & & \\
EE & 0.472 & 0.505 & $\mathbf{0 . 8 4 6}$ & & & & & & & \\
EQ & 0.597 & 0.556 & 0.556 & $\mathbf{0 . 9 0 5}$ & & & & & & \\
ET & 0.586 & 0.494 & 0.534 & 0.735 & $\mathbf{0 . 9 3 8}$ & & & & & \\
EXQ & 0.592 & 0.559 & 0.564 & 0.808 & 0.744 & $\mathbf{0 . 8 9}$ & & & & \\
IQ & 0.527 & 0.427 & 0.472 & 0.619 & 0.592 & 0.624 & $\mathbf{0 . 9 5 2}$ & & & \\
OQ & 0.611 & 0.431 & 0.524 & 0.684 & 0.68 & 0.701 & 0.772 & $\mathbf{0 . 9 2 1}$ & & \\
PEQ & 0.545 & 0.428 & 0.443 & 0.609 & 0.583 & 0.647 & 0.598 & 0.664 & $\mathbf{0 . 9 2 8}$ & \\
TS & 0.581 & 0.519 & 0.55 & 0.785 & 0.744 & 0.787 & 0.664 & 0.733 & 0.599 & $\mathbf{0 . 9 4 1}$ \\
\hline
\end{tabular}

Note: Bond font = square-root of the AVE (average variance extracted)

\section{The Results of Hypothesis Testing}

Table 4 and Figure 2 shows the results of PLS-SEM. The R-squares of EXQ, TS, ET, EE, and BS are 0.712, 0.619, 0.620, 0.338, and 0.295 respectively, indicating that the overall predictive power is moderate to high. By using SmartPLS, a bootstrapping process with 5000 samples was performed. The 
results indicate that PEQ $(B=0.152, t=4.184), O Q(B=0.158, t=3.802), A Q$ $(B=0.069, t=2.029)$, and $E Q(B=0.542, t=16.140)$ have significant positive effects on EXQ, but the results of IQ $(B=0.038, t=1.147)$ do not show a significant positive effect on EXQ; therefore, H1b, H1c, H1d, and H1e are supported but H1a is not supported.

Table 4. Results of the hypothesized model using PLS-SEM

\begin{tabular}{|c|c|c|c|c|c|}
\hline & & Path coefficient & t-statistics & VIF & Supported? \\
\hline & $\mathrm{R}^{2}$ value for $\mathrm{EXQ}=0.712$ & & & & \\
\hline H1a & $\mathrm{IQ} \rightarrow \mathrm{EXQ}$ & 0.038 & 1.147 & 2.625 & No \\
\hline $\mathrm{H} 1 \mathrm{~b}$ & $\mathrm{PEQ} \rightarrow \mathrm{EXQ}$ & 0.152 & 4.184 & 2.027 & Yes \\
\hline $\mathrm{H} 1 \mathrm{c}$ & $\mathrm{OQ} \rightarrow \mathrm{EXQ}$ & 0.158 & 3.802 & 3.385 & Yes \\
\hline H1d & $\mathrm{AQ} \rightarrow \mathrm{EXQ}$ & 0.069 & 2.029 & 1.814 & Yes \\
\hline \multirow[t]{2}{*}{ H1e } & $\mathrm{EQ} \rightarrow \mathrm{EXQ}$ & 0.542 & 16.140 & 2.237 & Yes \\
\hline & $\mathrm{R}^{2}$ value for $T S=0.619$ & & & & \\
\hline \multirow[t]{2}{*}{$\mathrm{H} 2$} & $\mathrm{EXQ} \rightarrow \mathrm{TS}$ & 0.787 & 36.951 & 1.000 & Yes \\
\hline & $R^{2}$ value for $E T=0.620$ & & & & \\
\hline Н3а & $\mathrm{EXQ} \rightarrow \mathrm{ET}$ & 0.415 & 8.036 & 2.623 & Yes \\
\hline \multirow[t]{2}{*}{$\mathrm{H} 3 \mathrm{~b}$} & $\mathrm{TS} \rightarrow \mathrm{ET}$ & 0.418 & 7.572 & 2.623 & Yes \\
\hline & $R^{2}$ value for $B S=0.295$ & & & & \\
\hline $\mathrm{H} 4 \mathrm{a}$ & $\mathrm{TS} \rightarrow \mathrm{BS}$ & 0.338 & 7.156 & 2.242 & Yes \\
\hline \multirow[t]{2}{*}{$\mathrm{H} 4 \mathrm{~b}$} & $\mathrm{ET} \rightarrow \mathrm{BS}$ & 0.242 & 5.166 & 2.242 & Yes \\
\hline & $R^{2}$ value for $E E=0.338$ & & & & \\
\hline $\mathrm{H} 5 \mathrm{a}$ & $\mathrm{TS} \rightarrow \mathrm{EE}$ & 0.342 & 6.287 & 2.242 & Yes \\
\hline $\mathrm{H} 5 \mathrm{~b}$ & $\mathrm{ET} \rightarrow \mathrm{EE}$ & 0.280 & 5.171 & 2.242 & Yes \\
\hline
\end{tabular}

Note: VIF $=$ Variance Inflation Factor

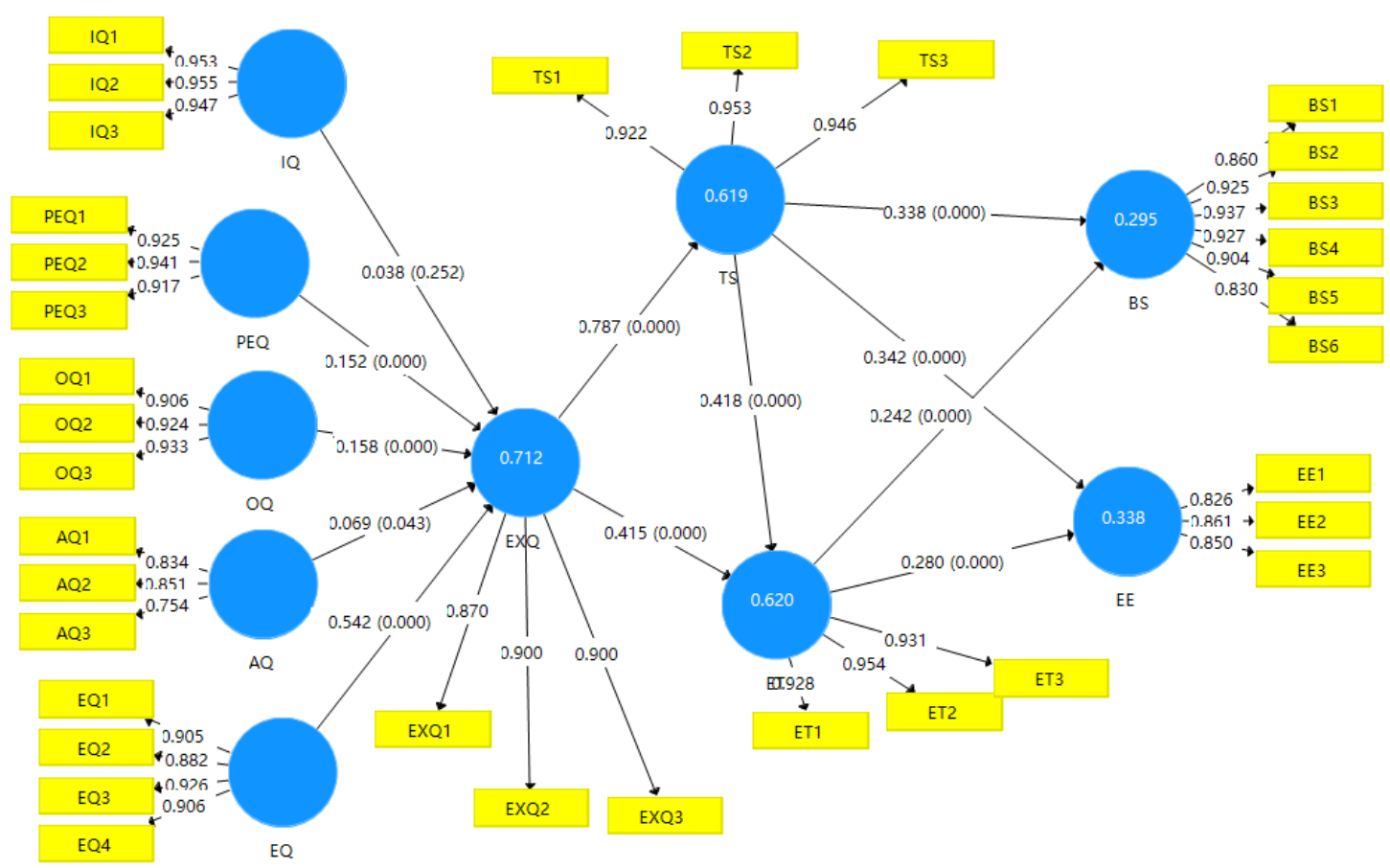

Figure 2. Results of PLS-SEM analysis 
The results also indicate that EXQ has a significant effect on TS (B = 0.787, $\mathrm{t}=36.951)$ and $\mathrm{ET}(\mathrm{B}=0.415, \mathrm{t}=8.036)$; TS has significant effects on $\mathrm{ET}(\mathrm{B}=0.418, \mathrm{t}=7.572)$; TS $(\mathrm{B}=0.338, \mathrm{t}=7.156)$ and $\mathrm{ET}(\mathrm{B}=0.242, \mathrm{t}=5.166)$ both have significant effects on $B S$; and TS $(B=0.342, t=6.287)$ and ET $(B=$ $0.280, t=5.171$ ) both have significant effects on EE. Hence, all the hypotheses from $\mathrm{H} 2$ to $\mathrm{H} 5$ are supported. Besides, all of the variable inflation factors are lower than 5, which indicates that the multicollinearity is not a serious issue in this study (Ringle et al., 2015).

\section{DISCUSSION AND CONCLUSION}

Hosting a sport tourism event is an effective way to promote local tourism development and creates profits for related industries. However, the study of experiential quality (EXQ) linked with sharing behavior on social media (BS) and extension effect (EE) is limited and needs stronger recognition in this field. Therefore, the current study empirically tested the relationships among EXQ, TS, ET, BS, and EE. Based on previous related research, this study highlights the outcomes of sharing behavior on social media (BS) and extension effect (EE) on sport tourism events. This critical study indicated that such sport tourism events could be an effective way to reach target markets and encourage tourists' trust (ET) and sharing behavior (BS), which, in turn, influence the extension effect (EE).

There are many findings from this study that are worthy of note. First, it provides a literature review of previous studies and relevant hypotheses that are based on a critical review of literature. The study also examines the five dimensions of EXQ in the MGP, which are PEQ, IQ, AQ, OQ, and EQ. The conceptual model is confirmed via SmartPLS by data collected from 796 participants in 2019. The results of the study showed that the hypotheses related to four dimensions - PEQ (H1b), OQ (H1c), AQ (H1d), and EQ (H1e) - all have significant effects on EXQ, in which EQ is perceived as the most significant dimension and followed by OQ and PEQ, respectively. These results support a previous study (Wu et al., 2017) that also concluded that EQ is perceived as the most important factor because the screaming and excitement of other tourists at the Grand Prix enhance tourists' sense of enjoyment. However, OQ as the second influenced dimension is a result that differs from the study of $\mathrm{Wu}$ et al. (2017). The finding of this study reveals that tourists are not satisfied with overall service outcome because interaction between tourists and staffs in MGP is quite weak, which tourists' demand is not fulfilled. This study's results related to physical environment as similar to those of Walter et al. (2010), 
both indicating that the surrounding environment (i.e., weather condition, nearby shops, etc.) may not satisfy tourists' demands. The results regarding $\mathrm{AQ}$ are also supported by some studies which found that accessibility during events has little impact on EXQ (Wu et al., 2014; Wong et al., 2015), thus, this dimension is listed last. By contrast, different from studies of Brady and Cronin (2001) and Wu et al. (2018a), the results of IQ are not supported. This is likely because, in the case of the Grand Prix, the interaction between workers and tourists is limited since most workers only have a chance to communicate to tourists upon check-in and the objective of most attendants is only to watch the game. These unique circumstances may be the reasons why IQ is not supported.

The second part of the study, hypotheses 2 through 5, is fully supported since each dimension had significant effects on the variables. The results revealed that EXQ $(\mathrm{H} 2)$ is significantly associated with TS, and EXQ (H3a) and TS (H3b) have significant effects on ET. This result is consistent with a previous study (Wu et al., 2018) concluded that good EXQ improves TS and ET. Accordingly, the results showed that TS is more likely to influence ET than EXQ. Also, TS (H4a) and ET (H4b) were found to have significant effects on BS. This result is consistent with Sotiriadis (2017), indicating that tourists are more likely to share relevant experiences on social media when they are satisfied with their participation in the activity; this is why TS has a stronger effect than ET on BS.

Based on previous related research and the 2020 COVID-19 pandemic, many mega-sport events are currently shutdown to decrease the risk of spreading the virus, which negatively impacts tourism destinations. However, some sport events such as the MGP are still being held as scheduled. This crisis has had a major impact on both events and hotels; as Lai and Wong (2020) discussed, all stakeholders should consider strategies for both the initial and follow-up pandemic stages of COVID-19. Thus, in relation to the current study, the government and organizers should put more attention on destination exposure rather than attracting a lot of visitors. In other words, the unique case of COVID-19 has made social media sharing far more important for destinations. The decreased number of tourists influences destination exposure, so government policies and advertising of such sport tourism events need to depend more on social media sharing. Social media is an important platform to encourage and inspire tourist engagement in live sport activities (Hayes, 2020), expand Macau's destination awareness, and attract more tourists in the future. Thus, sharing behavior on social media will have valuable implications for tourism destinations during the post-COVID-19 tourism recovery. 
It was also found that TS $(\mathrm{H} 5 \mathrm{a})$ and $\mathrm{ET}(\mathrm{H} 5 \mathrm{~b})$ are significantly related to EE. Consistent with the results of Song et al. (2017), TS during the event enhances tourists' awareness and perception of the Grand Prix, thus producing EE. ET has less effect than TS on EE, which indicates that tourists are more likely to lose their sense of trust after the Grand Prix. Instead, TS has a stronger effect, which means that tourists may buy commercial products after the MGP. As Wong and Lai (2019) discussed, online media is a good platform for all stakeholders to seek and share information, which, in turn, creates better interaction and partnerships with other stakeholders. Thus, BS and EE are significantly influential for creating benefits for the local economy.

\section{IMPLICATIONS}

\section{Theoretical Implications}

First, it should be noted that this study is one of the first to explore the functions of sharing behavior on social media (BS) and extension effect (EE) in the sport tourism event context. Most studies in event settings focus on traditional consequences after perception. Due to the impact of COVID-19, sport activities create a high risk of infection for attendees; therefore, events will be greatly affected by the pandemic and visitors may not be able to be involved in the sport events in person. However, these limited number of participants are crucial for promoting the events via social media; in other words, what these participants share through social media will influence other peoples' perceptions of the events. This study creates a new perspective from which to examine relationships between TS, ET, and BS. On the other hand, previous studies related to EE are mostly in the marketing field and do not provide many insights into tourism, and those that are within the tourism sector focus mostly on how EE is related to customer behavior outcomes. For example, Couto et al. (2017) found that EXQ and EE such as selling tickets and souvenirs are factors that positively influence TS. Extension activities and products significantly help the destination's tourism to grow faster; therefore, further research on EE in the tourism field is necessary to confirm since the topic of EE is a major gap in recent studies on sport tourism events. This study enriches previous literature and expands understandings of EXQ by exploring two new outcome variables.

Second, this study examines five dimensions of EXQ in sport tourism events and identifies comparative importance of each. As mentioned previously, EQ is confirmed as the most notable dimension in EXQ, 
followed by OQ, PEQ, and AQ. The results indicate that tourists' overall pleasure has the greatest effect on tourists' perception of EXQ because tourists at sport events are mostly concerned about enjoyment. In contrast, interactions that occur during the MGP have no effect because tourists are seldom concerned about interpersonal interaction. Previous studies on EXQ mostly focus on the heritage tourism field and airline field ( $\mathrm{Wu} \& \mathrm{Li}, 2017)$. The reason that data collection for sport events is limited is because of the duration of such events, which usually only last one to three days; this makes it more challenging to collect data in such a short period of time compared to other fields. Thus, the results of this study enrich the limited knowledge of EXQ in the context of sport tourism events. The revised measurement scale of experiential learning and other factors enable other researchers to apply EXQ to other hospitality and tourism sectors and provide researchers with the tools to revise the scales and apply them to other fields.

Third, this study focuses extensively on the relationships among EXQ, TS, ET, BS, and EE by providing a theoretical framework. The results confirmed that EXQ has the positive and significant effect on TS and ET; in other words, this positive relationship demonstrates that the higher EXQ of MGP tourists, the higher TS, and ET. The results also showed the positive relationship between TS, ET, and BS, EE, which means that tourists who are satisfied and trustworthy of the event are more likely to share their experiences on social media and buy extension products. This study applied the theories of EXQ and found that EXQ takes a leading role in driving BS and EE.

\section{Managerial implications}

The identified dimensions of EXQ helps practitioners with insight into how sport tourism event tourists in Macau form their perception of EXQ. The complex relationships between EXQ, TS, and behavioral intention provide management with greater insight into developing successful marketing strategies. In specific, sport tourism management should continually improve TS by recognizing the importance of EXQ. When planning an event, organizers and destination management organizations should consider improving TS based on importance of dimensions under different settings of EXQ. Moreover, because EQ was found to be the most important factor in this study, combining this event with visiting procedures is essential for increasing tourists' pleasure. For example, MGP officials usually cooperate with photographic gaming and auto show, whose information is shown on the official website. Tourists may go online to post 
their photos for a reward or locals could have the experience of auto show. In sum, the organizers of the event and the government can design more activities together with MGP to create a more pleasurable visitation for its participants. For instance, sport tourism event organizers can promote the motor-racing museum attraction after visiting MGP and hold more photographic activities for families. To enhance tourists' enjoyment perception, destinations should allocate more resources and a variety of activities.

OQ is the second most important factor that managers may consider when improving the overall service. More specifically, organizers should provide professional training for staffs to meet tourists' demands, since employees' performance gives the direct impression to tourists. Also, physical environment is important to improve experiences for tourists during the festival so that their sense of satisfaction is further increased. For example, organizers should understand tourists' preferences, keeping all areas as clean as possible, increasing seating to avoid narrow spaces, offering more self-convenient stations for drinks and food, enhancing the sounds of live music, and setting wide ranges of Wi-Fi. Although AQ was determined to be the least important dimension that influences EXQ in this study, the managers should still consider arranging convenient transportation and choosing accessible locations of the festival in the future. Lastly, since IQ is not supported in this study, the managers can devote less time to improving interaction between tourists and staff. For example, the designers may decide to add an interactive section to improve EXQ instead, or the organizers may design games for tourists to play during intermission to increase communication with staff. Also, they should recognize that IQ might not be important to all festivals. In the tourism field, although employees' interaction with participants seems to provide a significant image at first glance, managers should think critically about whether or not this dimension is necessary to EXQ. Thus, sport tourism event management needs to understand the sequence of EXQ regarding to the specific cultural settings. As Wong et al. (2019) concluded, when promoting a destination to tourists, it is important for destination marketers to address and highlight the appropriate theoretical construct, that being EXQ in this case. This information gives a guideline for management to measure visitor perception in sport tourism events.

In addition, this study helps sport tourism event management better understanding the effects of TS and ET on BS and EE. To increase profits, managers could come up with ways of promoting memorabilia because EE helps increasing brand or destination awareness and create benefits for the 
economy. In the case of the MGP, it is well known that the casino industry attracts an increasing number of tourists. EE is not only important in attracting more tourists but may also help increase the destination's image and promote the image of the Grand Prix in other countries. Therefore, the organizers of festivals should cooperate with the government better to create a representative brand image. Furthermore, sport tourism event management should place a strong focus on BS, which is one of the constructs in this study. The greater the exposure of the event on social media, the deeper the impressions that Macau and its events make on its tourists; as Stavrianea and Kavoura (2015) suggested, user-generated content on social media may be more effective in promoting events than traditional media. Sport tourism event management can thus provide promotional tickets of other attractions in Macau after tourists show the posted photos to staff in an effort to increase both destination tourism awareness and local brand awareness.

\section{Limitations and Future Studies}

Although this study gives contributions to academics and practitioners, the following limitations should be noted. First, this study does not consider cultural differences since the questionnaires were collected in Macau. Future studies may benefit from data collection in other regions or by examining conceptual research models in other countries and applying them in other tourism sectors. Second, this study mainly targets tourists even though some respondents were local residents. A further study could compare the perspectives of residents and tourists or different population groups such as resident-to-tourist, tourist-to-tourist, or company-to-tourist. Third, this study examines five dimensions of EXQ for tourist perception in sport tourism events. Other sub-dimensions of EXQ that are not included in the study could be developed in further studies. Lastly, this study discusses BS in the settings of sport tourism events during and postCOVID-19. A future study may consider a new pattern of sport tourism events, hybrid participation, which includes both face-to-face and online participation. In conclusion, this study enriches the literature on BS and EE in sport tourism events. Future research can expand the literature on other unexplored outcomes and study them from the residents' or other stakeholders' perspectives. 


\section{REFERENCES}

Alegre, J., \& Garau, J. (2010). Tourist satisfaction and dissatisfaction. Annals of Tourism Research, 37(1), 52-73.

Al-Msallam, S. (2020). The impact of tourists' emotions on satisfaction and destination loyalty-an integrative moderated mediation model: tourists' experience in Switzerland. Journal of Hospitality and Tourism Insights, 3(5), 509-528.

Arnegger, J., \& Herz, M. (2016). Economic and destination image impacts of mega-events in emerging tourist destinations. Journal of Destination Marketing $\mathcal{E}$ Management, 5(2), 76-85.

Bae, S. J., Lee, H., Suh, E.-K., \& Suh, K.-S. (2017). Shared experience in pretrip and experience sharing in posttrip: a survey of Airbnb users. Information $\mathcal{E}$ management, 54(6), 714-727.

Black, W. C., Babin, B. J., \& Anderson, R. E. (2010). Multivariate data analysis: a global perspective. Pearson, Bergen Country, NJ.

Brady, M. K., \& Cronin Jr, J. J. (2001). Some new thoughts on conceptualizing perceived service quality: a hierarchical approach. Journal of marketing, 65(3), 34-49.

Cetin, G. (2020). Experience vs quality: predicting satisfaction and loyalty in services. The Service Industries Journal, 40(15-16), 1167-1182.

Chang, T.-Y., \& Horng, S.-C. (2010). Conceptualizing and measuring experience quality: the customer's perspective. The Service industries journal, 30(14), 2401-2419.

Chen, C.-F., \& Chen, F.-S. (2010). Experience quality, perceived value, satisfaction and behavioral intentions for heritage tourists. Tourism Management, 31(1), 29-35.

Chen, C. K. (2016). Staging mass participation marathons in heritage tourism destinations: seeing through the eyes of distance runners. Journal of Touismology, 2(2), 2-12.

Chinomona, R. (2013). The influence of brand experience on brand satisfaction, trust and attachment in South Africa. International Business \& Economics Research Journal (IBER), 12(10), 1303-1316.

Chiu, C.-M., Hsu, M.-H., \& Wang, E. T. (2006). Understanding knowledge sharing in virtual communities: an integration of social capital and social cognitive theories. Decision support systems, 42(3), 1872-1888.

Choi, B. J., \& Kim, H. S. (2013). The impact of outcome quality, interaction quality, and peer-to-peer quality on customer satisfaction with a hospital service. Managing Service Quality: An International Journal, 23(3), 188-204.

Choi, C., \& Bum, C. H. (2020). Changes in the type of sports activity due to COVID-19: Hypochondriasis and the intention of continuous participation in sports. International Journal of Environmental Research and Public Health, 17(13), 4871.

Cole, S. T., \& Scott, D. (2004). Examining the mediating role of experience quality in a model of tourist experiences. Journal of Travel \& Tourism Marketing, 16(1), 79-90.

Corritore, C. L., Kracher, B., \& Wiedenbeck, S. (2003). On-line trust: concepts, evolving themes, a model. International Journal of Human-Computer Studies, 58(6), 737-758.

Couto, U. S., Lai Tang, W. S., \& Boyce, P. (2017). What makes a motorsports event enjoyable? The case of Macau Grand Prix. Journal of Convention \& Event Tourism, 18(1), 26-40.

Dacin, P. A., \& Smith, D. C. (1994). The effect of brand portfolio characteristics on consumer evaluations of brand extensions. Journal of Marketing Research, 31(2), 229-242.

Daniels, M. J., \& Norman, W. C. (2003). Estimating the economic impacts of seven regular sport tourism events. Journal of Sport Tourism, 8(4), 214-222. 
Dávid, L. D., Remenyik, B., Molnár, C., Baiburiev, R., \& Csobán, K. (2018). The Impact of the Hungaroring Grand Prix on the Hungarian Tourism Industry. Event Management, 22(4), 671-674.

Deery, M., Jago, L., \& Fredline, L. (2004). Sport tourism or event tourism: are they one and the same? Journal of Sport $\mathcal{E}$ Tourism, 9(3), 235-245.

del Bosque, I. R., \& Martín, H. S. (2008). Tourist satisfaction a cognitive-affective model. Annals of Tourism Research, 35(2), 551-573.

Duglio, S., \& Beltramo, R. (2017). Estimating the economic impacts of a small-scale sport tourism event: the case of the Italo-Swiss mountain trail CollonTrek. Sustainability, 9(3), 343.

Flavián, C., Guinalíu, M., \& Gurrea, R. (2006). The role played by perceived usability, satisfaction and consumer trust on website loyalty. Information $\mathcal{E}$ Management, 43(1), 1-14.

Foster, B. D., \& Cadogan, J. W. (2000). Relationship selling and customer loyalty: an empirical investigation. Marketing Intelligence \& Planning, 18(4), 185-199.

Gibson, H. J., Willming, C., \& Holdnak, A. (2003). Small-scale event sport tourism: fans as tourists. Tourism Management, 24(2), 181-190.

Gronroos, C. (1984). A service quality model and its marketing implications. European Journal of Marketing, 18(4), 36-44.

Grönroos, C. (1988). New competition in the service economy: the five rules of service. International Journal of Operations \& Production Management, 8(3), 9-19.

Gursoy, D., Yolal, M., Ribeiro, M. A., \& Panosso Netto, A. (2017). Impact of trust on local residents' mega-event perceptions and their support. Journal of Travel Research, 56(3), 393-406.

$\mathrm{Gu}$, Z. (2006). Product differentiation: Key to Macau's gaming revenue growth. Journal of Revenue and Pricing Management, 4(4), 382-388.

Han, A. F., Wong, K.-I., \& Ho, S. (2018). Residents' perceptions on the traffic impact of a special event: a case of the Macau Grand Prix. Asia Pacific Journal of Tourism Research, 23(1), 42-55.

Hair Jr, J. F., Hult, G. T. M., Ringle, C., \& Sarstedt, M. (2016). A primer on partial least squares structural equation modeling (PLS-SEM). Thousand Oaks, C. A.; Sage publications.

Hayes, M. (2020). Social media and inspiring physical activity during COVID-19 and beyond. Managing Sport and Leisure, 1-8.

He, X., Hu, D., Swanson, S. R., Su, L. \& Chen, X. (2018). Destination perceptions, relationship quality, and tourist environmentally responsible behavior. Tourism Management Perspectives, 28, 93-104.

Henderson, J. C., Foo, K., Lim, H., \& Yip, S. (2010). Sports events and tourism: the Singapore formula one grand prix. International Journal of Event and Festival Management, 1(1), 60-73.

Hinch, T. D., \& Higham, J. E. S. (2001). Sport tourism: a framework for research. International Journal of Tourism Research, 3(1), 45-58.

Hjalager, A.-M., \& Konu, H. (2011). Co-branding and co-creation in wellness tourism: the role of cosmeceuticals. Journal of Hospitality Marketing \& Management, 20(8), 879901.

Jin, N., Line, N. D., \& Yoon, D. (2018). Understanding the role of gratitude in building quality relationships. Journal of Hospitality Marketing \& Management, 27(4), 465-485.

Kang, M., \& Schuett, M. A. (2013). Determinants of sharing travel experiences in social media. Journal of Travel \& Tourism Marketing, 30(1-2), 93-107. 
Kao, Y.-F., Huang, L.-S., \& Wu, C.-H. (2008). Effects of theatrical elements on experiential quality and loyalty intentions for theme parks. Asia Pacific Journal of Tourism Research, 13(2), 163-174.

Kaplan, A. M., \& Haenlein, M. (2010). Users of the world, unite! The challenges and opportunities of Social Media. Business horizons, 53(1), 59-68.

Kim, D. K. (2020). The Relationship among Coach Support, Achievement Goal Orientations and Continuous Participation Intention for Golf Participants. Journal of the Korean Applied Science and Technology, 37(1), 133-144.

Kim, J., \& Fesenmaier, D. R. (2017). Sharing tourism experiences: the posttrip experience. Journal of Travel Research, 56(1), 28-40.

Kurtzman, J. (2005). Economic impact: sport tourism and the city. Journal of Sport Tourism, $10(1), 47-71$.

Lai, I. K. W., \& Wong, J. W. C. (2020). Comparing crisis management practices in the hotel industry between initial and pandemic stages of COVID-19. International Journal of Contemporary Hospitality Management, 32(10), 3135-3156.

Lai, I. K. W., \& Wong, J. W. C. (2021). From exhibitor engagement readiness to perceived exhibition performance via relationship quality. Journal of Hospitality and Tourism Management, 46, 144-152. https://doi.org/10.1016/j.jhtm.2020.12.004

Lee, C. L., \& Decker, R. (2009). A systematic analysis of preference change in co-branding. Journal of Applied Economic Sciences, 4(7), 36-44.

Lee, K. C., \& Chung, N. (2009). Understanding factors affecting trust in and satisfaction with mobile banking in Korea: a modified DeLone and McLean's model perspective. Interacting with Computers, 21(5-6), 385-392.

Lee, Y., In, J., \& Lee, S. J. (2020). Social media engagement, service complexity, and experiential quality in US hospitals. Journal of Services Marketing, 34(6), 833-845.

Lemke, F., Clark, M., \& Wilson, H. (2011). Customer experience quality: an exploration in business and consumer contexts using repertory grid technique. Journal of the Academy of Marketing Science, 39(6), 846-869.

López-Carril, S., Escamilla-Fajardo, P., González-Serrano, M. H., Ratten, V., \& GonzálezGarcía, R. J. (2020). The rise of social media in sport: a bibliometric analysis. International Journal of Innovation and Technology Management, 17(06), 2050041.

Lopez, S. J. (2011). The encyclopedia of positive psychology. Hoboken, New Jersey: John Wiley \& Sons.

Loureiro, S. M. C., \& González, F. J. M. (2008). The importance of quality, satisfaction, trust, and image in relation to rural tourist loyalty. Journal of Travel $\mathcal{E}$ Tourism Marketing, 25 (2), 117-136.

Lovegrove, H., \& Fairley, S. (2017). Using equity theory to understand non-host city residents' perceptions of a mega-event. Journal of Sport $\mathcal{E}$ Tourism, 21(1), 1-14.

Lu, Y., Zhang, L., \& Wang, B. (2009). A multidimensional and hierarchical model of mobile service quality. Electronic Commerce Research and Applications, 8(5), 228-240.

Munar, A. M., \& Jacobsen, J. K. S. (2014). Motivations for sharing tourism experiences through social media. Tourism Management, 43, 46-54.

Oliver, R. L. (1980). A cognitive model of the antecedents and consequences of satisfaction decisions. Journal of Marketing Research, 17(4), 460-469.

Otto, J. E., \& Ritchie, J. B. (1996). The service experience in tourism. Tourism Management, 17 (3), 165-174.

Perić, M., Vitezić, V., \& Mekinc, J. (2019). Comparing business models for event sport tourism: case studies in Italy and Slovenia. Event Management, 23(3), 379-397. 
Podoler, G. (2016). Running in the sun: the Pyongyang Marathon and its evolution into a sport tourism event. The International Journal of the History of Sport, 33(18), 22072225.

Reast, J. D. (2005). Brand trust and brand extension acceptance: the relationship. Journal of Product \& Brand Management, 14(1), 4-13.

Ringle, C. M., Wende, S., \& Becker, J.-M. (2015). SmartPLS 3. Bönningstedt, Germany: SmartPLS. In.

Risitano, M., Tutore, I., Sorrentino, A., \& Quintano, M. (2017). The influence of tourists' national culture on their behaviors in a sport mega-event. International Journal of Culture, Tourism and Hospitality Research, 11(2), 193-210.

Ritchie, B. W., \& Adair, D. (Eds.). (2004). Sport tourism: Interrelationships, impacts and issues (Vol. 14). Clevedon, Buffalo, Toronto: Channel View Publications.

Roche, M. (2002). Megaevents and modernity: Olympics and expos in the growth of global culture. London: Routledge.

Rose, S., Clark, M., Samouel, P., \& Hair, N. (2012). Online customer experience in eretailing: an empirical model of antecedents and outcomes. Journal of Retailing, 88(2), 308-322.

Rousseau, D. M., Sitkin, S. B., Burt, R. S., \& Camerer, C. (1998). Not so different after all: a cross-discipline view of trust. Academy of Management Review, 23(3), 393-404.

Ryu, G., \& Feick, L. (2007). A penny for your thoughts: referral reward programs and referral likelihood. Journal of Marketing, 71(1), 84-94.

Shonk, D. J., \& Chelladurai, P. (2008). Service quality, satisfaction, and intent to return in event sport tourism. Journal of Sport Management, 22(5), 587-602.

Song, H. J., Bae, S. Y., \& Lee, C.-K. (2017). Identifying antecedents and outcomes of festival satisfaction. International Journal of Contemporary Hospitality Management, 29(3), 947965.

Song, H., Kim, M., \& Choe, Y. (2019). Structural relationships among mega-event experiences, emotional responses, and satisfaction: Focused on the 2014 Incheon Asian Games. Current Issues in Tourism, 22(5), 575-581.

Sorrentino, A., Fu, X., Romano, R., Quintano, M., \& Risitano, M. (2020). Measuring event experience and its behavioral consequences in the context of a sports megaevent. Journal of Hospitality and Tourism Insights, 3(5), 589-605.

Sotiriadis, M. D. (2017). Sharing tourism experiences in social media. International Journal of Contemporary Hospitality Management, 29(1), 179-225.

Sox, C. B., Sox, M. M., \& Campbell, J. M. (2020). Giving light to mega-event planning: residents' perceptions on total eclipse weekend. International Journal of Event and Festival Management, 11(2), 203-221.

Stavrianea, A., \& Kavoura, A. (2015). Social media's and online user-generated content's role in services advertising. Paper presented at the AIP conference proceedings, 17 Feb, Ekaterinburg, Russia.

Swanson, S. R., Davis, J. C., \& Zhao, Y. (2007). Motivations and relationship outcomes: the mediating role of trust and satisfaction. Journal of Nonprofit $\mathcal{E}$ Public Sector Marketing, 18(2), 1-25.

Tang, J., \& Wang, Y. (2020). Does tourism sports event make residents happier? Exploring the SWB of Macau residents in the case of Macau Grand Prix. Journal of Tourism and Cultural Change, 1-19. DOI: 10.1080/14766825.2019.1711103

Völckner, F., \& Sattler, H. (2006). Drivers of brand extension success. Journal of Marketing, 70(2), 18-34. 
Walter, U., Edvardsson, B., \& Öström, Å. (2010). Drivers of customers' service experiences: a study in the restaurant industry. Managing Service Quality: An International Journal, 20(3), 236-258.

Wang, C., Lu, L., \& Xia, Q. (2012). Impact of tourists' perceived value on behavioral intention for mega events: Analysis of inbound and domestic tourists at Shanghai World Expo. Chinese Geographical Science, 22(6), 742-754.

Wong, J. W. C., \& Lai, I. K. W. (2019). The effects of value co-creation activities on the perceived performance of exhibitions: A service science perspective. Journal of Hospitality and Tourism Management, 39, 97-109.

Wong, J. W. C., Lai, I. K. W., \& Tao, Z. (2019). Memorable ethnic minority tourism experiences in China: a case study of Guangxi Zhuang Zu. Journal of Tourism and Cultural Change, 17(4), 508-525.

Wong, J. W. C., Lai, I. K. W., \& Tao, Z. (2020). Sharing memorable tourism experiences on mobile social media and how it influences further travel decisions. Current Issues in Tourism, 23(14), 1773-1787.

Wong, J., Wu, H. C., \& Cheng, C. C. (2015). An empirical analysis of synthesizing the effects of festival quality, emotion, festival image and festival satisfaction on festival loyalty: A case study of Macau Food Festival. International Journal of Tourism Research, 17(6), 521-536.

$\mathrm{Wu}$, H.-C., \& Ai, C.-H. (2016). Synthesizing the effects of experiential quality, excitement, equity, experiential satisfaction on experiential loyalty for the golf industry: the case of Hainan Island. Journal of Hospitality and Tourism Management, 29, 41-59.

Wu, H. C., Ai, C. H., \& Cheng, C. C. (2016). Synthesizing the effects of green experiential quality, green equity, green image and green experiential satisfaction on green switching intention. International Journal of Contemporary Hospitality Management, 28(9), 2080-2107.

Wu, H.-C., Cheng, C.-C., \& Ai, C.-H. (2018). A study of experiential quality, experiential value, trust, corporate reputation, experiential satisfaction and behavioral intentions for cruise tourists: the case of Hong Kong. Tourism Management, 66, 200220.

Wu, H.-C., Cheng, C.-C., \& Hong, W. (2017). An assessment of zoo visitors' revisit intentions. Tourism Analysis, 22(3), 361-375.

Wu, H.-C., Li, M.-Y., \& Li, T. (2018a). A study of experiential quality, experiential value, experiential satisfaction, theme park image, and revisit intention. Journal of Hospitality \& Tourism Research, 42(1), 26-73.

$\mathrm{Wu}, \mathrm{H} .-\mathrm{C} .$, \& Li, T. (2017). A study of experiential quality, perceived value, heritage image, experiential satisfaction, and behavioral intentions for heritage tourists. Journal of Hospitality \& Tourism Research, 41(8), 904-944.

Wu, H.-C., Wong, J. W.-C., \& Cheng, C.-C. (2014). An empirical study of behavioral intentions in the food festival: the case of Macau. Asia Pacific Journal of Tourism Research, 19(11), 1278-1305.

Yuan, Y.-H. E., \& Wu, C. K. (2008). Relationships among experiential marketing, experiential value, and customer satisfaction. Journal of Hospitality $\mathcal{E}$ Tourism Research, 32(3), 387-410.

Zhang, J., Byon, K. K., Williams, A. S., \& Huang, H. (2019). Effects of the event and its destination image on sport tourists' attachment and loyalty to a destination: the cases of the Chinese and US Formula One Grand Prix. Asia Pacific Journal of Tourism Research, 24(12), 1169-1185. 